\title{
A Case Study: Foundation Design in Liquefiable Site
}

\author{
Tahar Ayadat* \\ *(Department of Civil Engineering, College of Engineering, PMU University, P.O. Box 1664, Al-Khobar, \\ 31952, Saudi Arabia.Email: tayadat@pmu.edu.sa)
}

\begin{abstract}
The liquefaction is a phenomenon which occurs under seismic solicitation. The passage of a seis mic wave (i.e. strong shaking) leads, in certain geological formations, to the loss of shearing resistance in saturated sandy materials. This is caused mainly by the increase of the pore water pressure generated by the cyclical deformations. The instantaneous deconsolidation of the soil is reflected by the destruction of the soil mass; making the constructions on such soils unstable. In this geotechnical investigation a case study of foundation design on liquefiable site is described. The geotechnical investigation, carried out at Kent (Ontario), consisted of the construction of a new electrical station on a liquefiable site.
\end{abstract}

Keywords - case study, foundation, design, liquefaction, remedial measures.

\section{INTRODUCTION}

The Liquefaction is a phenomenon in which the shear strength of a soil is reduced by shaking caused by an earthquake or another fast loading. The liquefaction occurs generally in saturated granular soils. The presence of water within the soil mass causes (during shaking) an increase of the pore water pressure on the soil particles; leading to a reduction of the actual effective lateral pressure in the soil. This leads to a decrease of the resistance to shearing of the soil; which at the ultimate status could become zero. The liquefaction of the soil is a serious problem that can cause damage, often irreversible, both to existing or new constructions.

The present investigation represents a detailed example of foundation design on liquefiable site. It consists of a geotechnical investigation carried out at Kent (Ontario) in order to build a new electrical station. The site is almost rectangular of about $200 \mathrm{~m}$ width and $300 \mathrm{~m}$ length.

The project can be divided into three parts, including two areas of $230 \mathrm{kV}$ and $27.6 \mathrm{kV}$, and an access road. The $230 \mathrm{kV}$ included two transformer sites with spill contain ment and transformer bases and the electrical installation at the line entrance founded on pier. The $27.6 \mathrm{kV}$ area included many electrical installation founded on single or double pier (Figure 1).

The purpose of this investigation was to determine the nature and the geotechnical properties of the subsurface soil from the result of test boring and by means of field and laboratory works. This information is to provide foundation design criteria for the various elements of the proposed construction. This paper contains a description of the site, methodology and result of the site investigation and laboratory work, and the recommendations on a)- site suitability with regard to the proposed method of construction, b)- soil engineering properties ground water level depth, c)- technical consideration of soil type and condition, d)-soil bearing capacity and soil settlement condition, and e)- liquefaction and seismic design consideration of soil.

\section{FIELD AND LABORATORY WORKS UNDERTAKEN}

The field work was performed by the end of July, 2010. Fourteen (14) vertical boreholes with soil sampling were performed and are identified as follows: four boreholes in the $230 \mathrm{kV}$ area, (noted as BH-01-10 to BH-04-10), two boreholes in the 27,6 $\mathrm{kN}$ area (noted as $\mathrm{BH}-07-10$ and $\mathrm{BH}-08-10$ ), eight boreholes in the road area (noted as BH-05-10 to BH-06-10 and BH-09-10 to BH-14-10). Boreholes reached depths between $3.0 \mathrm{~m}$ and $11.3 \mathrm{~m}$. During the drilling operation, remolded samples of soil were obtained at interval of 0.6 to $1.5 \mathrm{~m}$ depth. Furthermore, in borehole BH-01-10, dynamic penetration test as per specification BNQ-2501-145, was carried out after the end of the sampling process up to a depth of about $10 \mathrm{~m}$.

Piezometers were installed in the holes of five boreholes (BH-01-10, BH-02-10, BH-07-10, BH-09-10 and BH-14-10), before the withdrawal of the casing, for future observation of ground water level.

The locations of the different boreholes are indicated in Figure 1. It is worthy to note that, a standard "B" split spoon, with an inside diameter of $38 \mathrm{~mm}$, was used to perform the standard penetration test (SPT) as per specification BNQ2501-140. In order to increase the soil recovery following a poor recuperation of sample, a " $\mathrm{N}$ ", 
split spoon with an inside diameter of $50 \mathrm{~mm}$ was used. It should be noted that the standard penetration values $(\mathrm{N})$ given in this reports correspond to raw values obtained on the ground, without correction.

All soil samples recovered were sent for visual examination and further identification by means of a laboratory test program. The tests enumerated in Table 1 were performed on representative samples in order to determine the nature and some physical properties of soils.

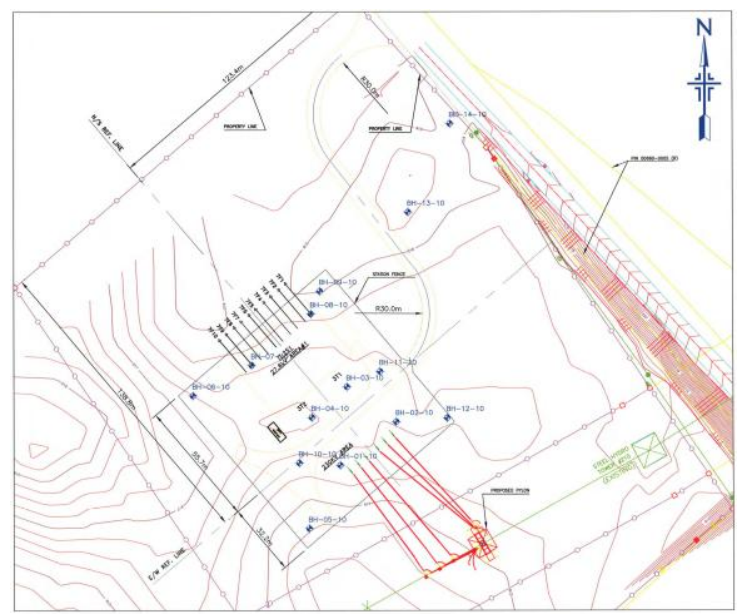

Figure 1. Project Layout and Boreholes' Location

Table 1. Geotechnical laboratory tests

\begin{tabular}{|c|c|c|}
\hline Laboratory test & Standard & Quantity \\
\hline 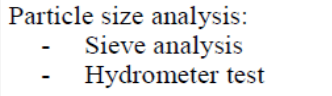 & $\begin{array}{c}\text { LC 21-040 } \\
\text { (ASTM D421) }\end{array}$ & $\begin{array}{c}16 \\
6\end{array}$ \\
\hline Water content determination & $\begin{array}{l}\text { BNQ 2501-170 } \\
\text { (ASTM D2216) }\end{array}$ & 26 \\
\hline $\begin{array}{l}\text { Liquidity and plasticity } \\
\text { limits (Atterberg Limits) }\end{array}$ & BNQ 2501-092 & 5 \\
\hline
\end{tabular}

\section{SOIL DESCRIPTION}

The field drilling operation, carried out at the location of the projected station, has revealed several soil deposits with different properties. Generally and for simplicity, the site is made up of three horizons. On the surface, a thin layer made up of sandy top soil followed by a layer of fine to coarse brown sand of approximately 4.5 meter thickness to finish in a stiff layer of clay and silt. The stratigraphy of the site as encountered in the different boreholes is described in Table 2 and summarized in the following sub-sections.

The ground water level was monitored by five (5) piezo meter installed in boreholes BH-01-10, BH-02-10, BH-07-10, BH-09-10 and BH-14-10. The different water levels measured on the $29^{\text {th }}$ of July are indicated in Table 3.
Table 2. Stratigraphy of the investigated site

\begin{tabular}{|l|c|c|c|}
\hline Borehole & $\begin{array}{c}\text { Sandy top soil } \\
\text { (Deposit A, m) }\end{array}$ & $\begin{array}{c}\text { Brown sand } \\
\text { (Deposit B, m) }\end{array}$ & $\begin{array}{c}\text { Silt and clay } \\
\text { (Deposit C, m) }\end{array}$ \\
\hline BH-01-10 & $0.0-0.20$ & $0.20-4.57$ & $4.57->6.71$ \\
\hline BH-02-10 & $0.0-0.20$ & $0.20-4.57$ & $4.57->6.71$ \\
\hline BH-03-10 & $0.0-0.30$ & $0.30-3.99$ & $3.99->11.28$ \\
\hline BH-04-10 & $0.0-0.30$ & $0.30-4.42$ & $4.42->11.28$ \\
\hline BH-05-10 & $0.0-0.20$ & $0.20->3.05$ & - \\
\hline BH-06-10 & $0.0-0.20$ & $0.20->3.05$ & - \\
\hline BH-07-10 & $0.0-0.20$ & $0.20->3.05$ & - \\
\hline BH-08-10 & $0.0-0.20$ & $0.20->3.05$ & - \\
\hline BH-09-10 & $0.0-0.20$ & $0.20-5.61$ & $5.61->6.71$ \\
\hline BH-10-10 & $0.0-0.20$ & $0.20->3.05$ & - \\
\hline BH-11-10 & $0.0-0.20$ & $0.20->3.05$ & - \\
\hline BH-12-10 & $0.0-0.22$ & $0.22->3.05$ & - \\
\hline BH-13-10 & $0.0-0.20$ & $0.20-2.60$ & $2.60->3.05$ \\
\hline BH-14-10 & $0.0-0.30$ & $0.30-5.33$ & $5.33->6.71$ \\
\hline
\end{tabular}

Table 3. Ground water level

\begin{tabular}{|c|c|}
\hline Measurement points & Water level (m) \\
\hline BH-01-10 & 1.96 \\
\hline BH-02-10 & 1.86 \\
\hline BH-07-10 & 1.98 \\
\hline BH-09-10 & 2.65 \\
\hline BH-14-10 & 2.82 \\
\hline
\end{tabular}

\section{III.1 Deposit A: Sandy top soil}

At the ground surface, a thin sandy layer with some vegetable roots was identified in almost all the boreholes performed in the area of the project. The thickness of the sampled layer varied between 0.20 and $0.30 \mathrm{~m}$. It is constituted generally by a matrix of brown sand mixed with some organic matter and vegetables roots in different proportions.

\section{III.2 Deposit B: Brown sand}

A thick deposit of fine to coarse, brown and dry to saturate homogenous sandy soil was encountered below the deposit $\mathrm{A}$ in all boreholes. The thickness of the sampled layer varied between $2.4 \mathrm{~m}$ and $5.4 \mathrm{~m}$. The value of the index of the standard penetration test in all layers is situated generally between 2 and 37, indicating that the soil is generally in loose to medium-dense state.

Sixteen (16) sieve analyses were performed on samples taken from this layer of brown sand. The results of the different tests are grouped in Table 4. The results of the particle size distributions indicated that, in the exception of borehole BH-1110 , the soil is composed of 0 to $13 \%$ of gravel, $60 \%$ to $94 \%$ of sand, and about $8 \%$ to $26 \%$ of silt (particles less than $80 \mu \mathrm{m}$ ). Generally, the soil of 
this layer can be classified as sand with some silt and traces of gravel.

Table 4. Su mmary of sieve analysis results (Deposit B: brown sand)

\begin{tabular}{|l|c|c|c|c|c|}
\hline Borehole/Sample & Depth (m) & $\begin{array}{c}\% \text { of } \\
\text { gravel }\end{array}$ & $\begin{array}{c}\text { \% of } \\
\text { sand }\end{array}$ & $\begin{array}{c}\% \\
\text { of silt }\end{array}$ & Description \\
\hline BH-01-10; SS-03 & 1.22 to 1.83 & 0.23 & 88.86 & 10.91 & Sand with little silt \\
\hline BH-02-10; SS-02 & 0.61 to 1.22 & 5.89 & 94.11 & - & Sand with traces of gravel \\
\hline BH-03-10; SS-03 & 1.22 to 1.83 & 1.29 & 83.70 & 15.01 & Sand with little silt and traces of gravel \\
\hline BH-03-10; SS-05 & 2.44 to 3.05 & 13.08 & 60.78 & 26.14 & Silty sand with little gravel \\
\hline BH-04-10; SS-02 & 0.61 to 1.83 & 0.63 & 81.29 & 18.08 & Sand with little silt \\
\hline BH-04-10; SS-07 & 3.81 to 4.42 & 6.39 & 81.25 & 12.36 & Sand with little silt and traces of gravel \\
\hline BH-05-10; SS-05 & 2.44 to 3.05 & - & 92.07 & 7.93 & Sand with traces of silt \\
\hline BH-06-10; SS-04 & 1.83 to 2.44 & 1.79 & 76.4 & 21.81 & Silty sand with traces of gravel \\
\hline BH-07-10; SS-03 & 1.22 to 1.83 & 2.72 & 81.47 & 15.81 & Sand with little silt and traces of gravel \\
\hline BH-08-10; SS-02 & 0.61 to 1.22 & 5.02 & 75.80 & 19.18 & Sand with little silt and traces of gravel \\
\hline BH-09-10; SS-03 & 1.22 to 1.83 & 1.32 & 89.68 & 9.00 & Sand with traces of silt and gravel \\
\hline BH-10-10; SS-02 & 0.61 to 1.22 & 0.93 & 78.56 & 20.51 & Sand with little silt and traces of gravel \\
\hline BH-11-10; SS-04 & 1.83 to 2.44 & 0.24 & 47.85 & 51.91 & Sand and silt \\
\hline BH-12-10; SS-01 & 0.00 to 0.61 & 8.90 & 74.96 & 16.14 & Sand with little silt and traces of gravel \\
\hline BH-13-10; SS-04 & 1.83 to 2.44 & 7.26 & 82.75 & 9.99 & Sand with traces of silt and gravel \\
\hline BH-14-10; SS-03 & 1.22 to 1.83 & 7.42 & 71.77 & 20.81 & Silty sand with traces of gravel \\
\hline
\end{tabular}

\section{III.3 Deposit C: Silt and clay}

A thick layer of silt and clay, brown to grey, mainly saturated was encountered in the boreholes BH-01-10 to BH-04-10, BH-09-10, BH13-10 and BH-14-10. The thickness of the sampled layer varied between $0.4 \mathrm{~m}$ and $7.3 \mathrm{~m}$. In the exception of borehole BH-13-10, the different values of the index of standard penetration test $\mathrm{N}$ are generally in the range of 12 to 28 , which indicate that the deposit $\mathrm{C}$ is stiff to very stiff.

Six hydrometer tests were carried out on different samples taken from the layer of silt and clay in boreholes BH-01-10 to BH-04-10, BH-09-10 and $\mathrm{BH} 14-10$. The results of the different tests are grouped in Table 5. Generally, the results obtained indicate that the soils encountered in this layer are composed of $4 \%$ to $20 \%$ of sand, $42 \%$ to $58 \%$ of silt (particles less than $80 \mu \mathrm{m}$ ) and $30 \%$ to $53 \%$ of clay (particles less than $2 \mu \mathrm{m}$ ). The soils can be classified as silt and clay with little/traces of sand.

Some mo isture content and Atterberg limits measurements were performed on samples taken from this layer and the results of the different tests are summarized in Table 6. According to the results of consistency tests carried out on samples of silt and clay, the liquid limit of these soils is in the range of $29 \%$ and $40 \%$, and the plastic limit is in the range of $15 \%$ and $19 \%$. Then, the mo is ture content values are lower than the liquid limit, which indicate that the silt and clay is not sensitive. Based on these results, the silt and clay soil is classified as soil of type CL2 (low plasticity).

Based on visual examinations carried out by our professionals on samples taken from the boreholes and the different recorded values of SPT index N (varying between 14 and 29) and further the results of the dynamic penetration test performed in borehole BH-01-10, it was confirmed that the silt and clay is stiff to very stiff. Furthermore, according to the correlation established in literature [1] between the values of $\mathrm{N}$ and undrained shear strength of clay, it can be estimated that the value of the undrained shear strength $\left(C_{u}\right)$ of silt and clay varies between $85 \mathrm{kPa}$ and $180 \mathrm{kPa}$.

Table 5. Su mmary of hydrometer test results

\begin{tabular}{|c|c|c|c|c|c|}
\hline Borehole/Sample & Depth (m) & $\begin{array}{c}\% \\
\text { of sand }\end{array}$ & $\begin{array}{c}\% \\
\text { of silt }\end{array}$ & $\begin{array}{c}\% \\
\text { of clay }\end{array}$ & Description \\
\hline BH-01-10; SS-09 & 5.33 to 5.94 & 8.44 & 42.39 & 49.17 & Clay and silt with traces of sand \\
\hline BH-02-10; SS-08 & 4.57 to 5.18 & 4.36 & 57.94 & 29.90 & Clayey silt with traces of sand \\
\hline BH-03-10; SS-13 & 10.67 to 11.28 & 17.0 & 46.49 & 36.51 & Silt and clay with little sand \\
\hline BH-04-10; SS-12 & 9.14 to 9.75 & 16.79 & 45.01 & 38.20 & Silt and clay with little of sand \\
\hline BH-09-10; SS-09 & 5.33 to 5.94 & 5.53 & 41.65 & 52.82 & Clay and silt with traces of sand \\
\hline BH-14-10; SS-09 & 5.33 to 5.94 & 19.97 & 44.81 & 35.22 & Silt and clay with little sand \\
\hline
\end{tabular}

Table 6. Su mmary of mo is ture content and Atterberg limits measurements

\begin{tabular}{|c|c|c|c|c|c|c|c|}
\hline Borehole/Sample & Depth (m) & W $(\%)$ & $\begin{array}{l}\text { Liquid } \\
\text { limit (\%) }\end{array}$ & $\begin{array}{c}\text { Plastic } \\
\text { Limit } \\
(\%)\end{array}$ & $\begin{array}{l}\text { Plasticity } \\
\text { Index \% }\end{array}$ & $\begin{array}{l}\text { Liquidity } \\
\text { Index \% }\end{array}$ & \begin{tabular}{|c|c} 
Unified \\
Classifica \\
tion \\
(USCS) \\
\end{tabular} \\
\hline BH- $01-10 ;$ SS-04 & 1.83 to 2.44 & 25.3 & & & & & \\
\hline BH-01-10; SS-06 & 3.05 to 3.66 & 22.6 & & & & & \\
\hline BH- $01-10 ;$ SS-00 & 5.33 to 5.94 & 22.9 & 39.9 & 19.1 & 20.8 & 0.19 & CL2 \\
\hline BH-02-10; SS-05 & 2.44 to 3.05 & 11.6 & & & & & \\
\hline BH-02-10; SS-07 & 3.81 to 4.42 & 21.5 & & & & & \\
\hline BH- $03-10 ;$ SS-02 & 0.61 to 1.22 & 12.8 & & & & & \\
\hline BH-03-10; SS-06 & 3.05 to 3.66 & 23.3 & & & & & \\
\hline BH-03-10; SS-12 & 9.14 to 9.78 & 18.2 & & & & & \\
\hline BH-03-10; SS-13 & 10.67 to 11.28 & 14.3 & 31.2 & 17.1 & 14.1 & -0.20 & CL2 \\
\hline BH-04-10; SS-03 & 1.22 to 1.83 & 23.6 & & & & & \\
\hline BH-04-10; SS-06 & 3.05 to 3.66 & 16.1 & & & & & \\
\hline BH- $04-10 ;$ SS-12 & 9.14 to 9.75 & 18.3 & 31.6 & 15.4 & 16.2 & 0.18 & CL2 \\
\hline BH-04-10; SS-13 & 10.67 to 11.28 & 18.4 & & & & & \\
\hline BH-05-10; SS-04 & 1.83 to 2.44 & 8.0 & & & & & \\
\hline BH-06-10; SS-02 & 0.61 to 1.22 & 7,0 & & & & & \\
\hline BH-06-10; SS-05 & 2.44 to 3.05 & 17.4 & & & & & \\
\hline BH- $07-10 ;$ SS-02 & 0.61 to 1.22 & 11.1 & & & & & \\
\hline BH-07-10; SS-04 & 1.83 to 2.44 & 21.9 & & & & & \\
\hline BH-08-10; SS-04 & 1.83 to 2.44 & 19.1 & & & & & \\
\hline BH-09-10; SS-02 & 0.61 to 1.22 & 8.7 & & & & & \\
\hline BH-09-10; SS-07 & 3.81 to 4.42 & 15.2 & & & & & \\
\hline BH-09-10; SS-09 & 5.33 to 5.94 & 22.4 & 39.4 & 18.8 & 20.6 & 0.17 & CL2 \\
\hline BH-10-10; SS-04 & 1.83 to 2.44 & 19.6 & & & & & \\
\hline BH-11-10; SS-02 & 0.61 to 1.22 & 8.0 & & & & & \\
\hline BH-12-10; SS-05 & 2.44 to 3.05 & 12.0 & & & & & \\
\hline BH-13-10; $\mathrm{SS}-02$ & 0.61 to 1.22 & 10.2 & & & & & \\
\hline BH-13-10; SS-05 & 2.44 to 3.05 & 33.5 & & & & & \\
\hline BH-14-10; SS-01 & 0.00 to 0.61 & 11.6 & & & & & \\
\hline BH-14-10; SS-04 & 1.83 to 2.44 & 23.5 & & & & & \\
\hline BH-14-10; SS-09 & 5.33 to 5.94 & 16.8 & 29.2 & 15.5 & 13.7 & 0.09 & $\mathrm{CL} 1$ \\
\hline BH-14-10; SS-10 & 6.10 to 6.71 & 16.1 & & & & & \\
\hline
\end{tabular}

\section{Site Se ismic Category And Assess ment Of Soil Liquefaction}

The deposit B, classified as granular soil (mainly composed of sand), is loose to mediumdense and mostly saturated. Consequently, a verification of susceptibility to liquefaction was carried out using the method proposed by Prakash [2] with a maximum acceleration factor at the surface of 0.2 , corresponding to a probability of going beyond $10 \%$ in 50 years. This acceleration factor was obtained by interpolation using the interpolation tool of seismic values addressed by Canada natural resources.

The calculations performed for verification are based on the values of the standard penetration index, N. The results obtained showed that the deposit B of brown sand is susceptible to liquefaction (Figures 2 to 4 ). In these Figure, if the 
curve representing the shearing stress due to earthquake $\left(T_{a v}\right)$ is situated above the curve of the critical shearing resistance of the soil $\left(T_{c r}\right)$ at a given depth, then the soil is susceptible to liquefaction.

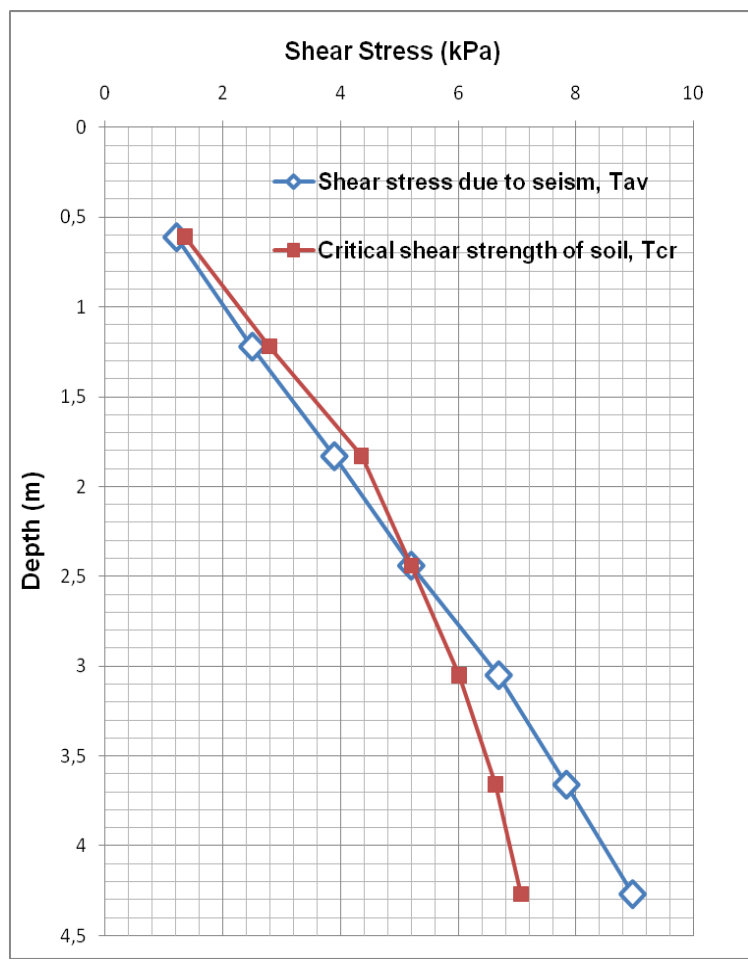

Figure 2. Verification of susceptibility to liquefaction (BH-02-10)

Generally, site seismic categories are function of the ground type and the mean velocity of the waves of shearing, $\overline{V_{s}}$. However, if this speed is unknown, it is necessary to determine the category of the site using the average resistance of the standard penetration test, where the values are subjected to an energetic correction $\overline{N_{60}}$, in accordance with the requirements of the National Code of Construction (Canada). Based on the calculated modified standard penetration index, the category of site of the brown sand is normally $E$. However, considering the brown sand as potentially liquefiable, the category of the site in this case is F. Furthermore, if the liquefiable soil is excavated and replaced by compacted granular fill or if foundations are sited or embedded in the stiff to very stiff silt and clay deposit (with $C_{u}$ mostly greater than 100 $\mathrm{kPa}$, section 6.2), the category of the site will be C.

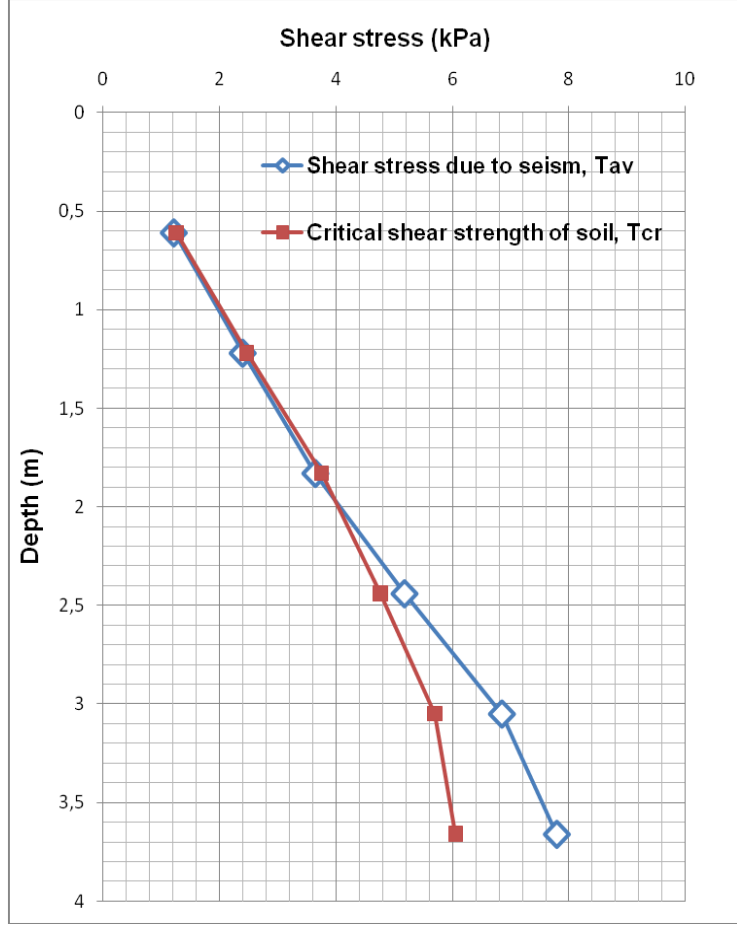

Figure 3. Verification of susceptibility to liquefaction (BH-03-10)

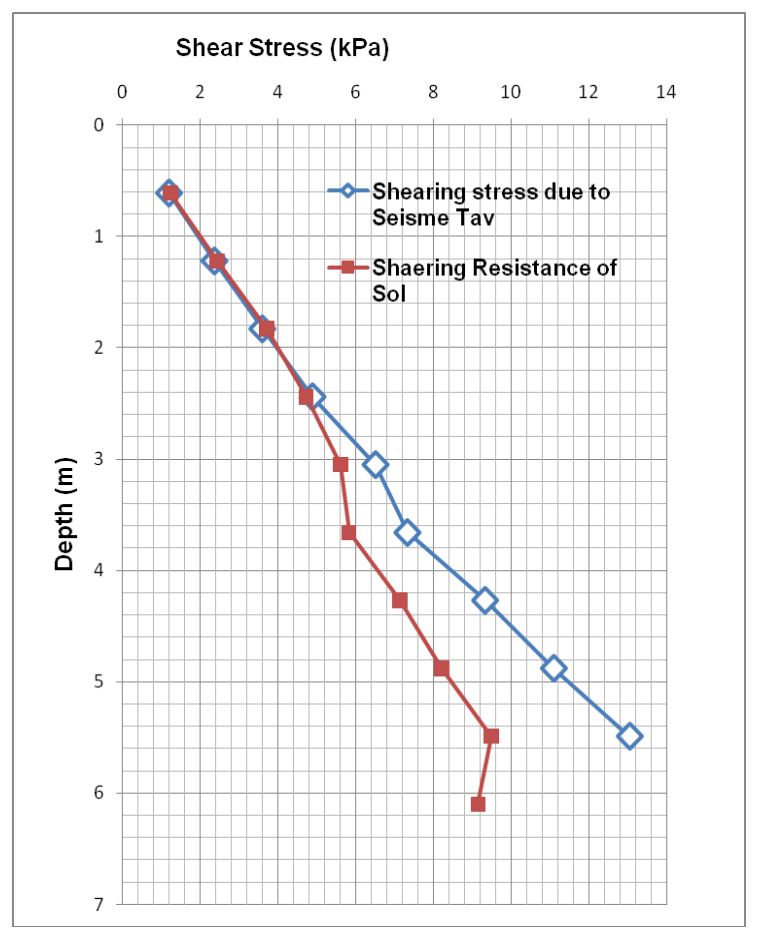

Figure 4. Verification of susceptibility to liquefaction (BH-09-10)

\section{DESIGN OF FOUNDATION}

As mentioned previously, the project consisted on the construction of a new electrical station located in the municipality of Kent (Ontario). In the $230 \mathrm{kV}$ area, the two transformer foundation is a rectangular base of $4.0 \times 8.0 \mathrm{~m}$ each located in a 
spill containment of $15.4 \mathrm{~m} \mathrm{x} 13.6 \mathrm{~m}$. The electrical installation of the south part of the $230 \mathrm{kV}$ area (at the line entrance) and in the $27.6 \mathrm{kV}$ area are founded on single or double pier with $0.8 \mathrm{~m}$ to $2.4 \mathrm{~m}$ diameter at their base.

The boreholes showed that the site is composed mainly by three deposits: a thin layer of sandy top soil of 0.2 to $0.3 \mathrm{~m}$ thickness followed by a thick deposit of loose to compact brown sand of 2.4 to $5.4 \mathrm{~m}$. Under the layer of sand, a deposit of stiff to very stiff silt and clay of 0.4 to $7.3 \mathrm{~m}$ thickness was intercepted. In the basis of the results of the different boreholes and the laboratory test program, the following remarks and recommendations were retained.

From a strictly geotechnical point of view, organic matters, frozen ground, and all filling materials, if intercepted, are inadequate to support any part of the construction and should be excavated up to the level of natural soil in all the area of the projected station. Furthermore, based on the fact that the deposit B (2.4 $\mathrm{m}$ to $5.4 \mathrm{~m}$ thickness $)$ is potentially liquefiable, the loads of the new structure must be transmitted to the ground with: i) - shallow foundation sited on the stiff to very stiff silt and clay deposit (C), ii)- by means of deep foundations such as piles or stone columns embedded in deposit $\mathrm{C}$, or iii)- to consider the case of excavating the deposit $\mathrm{B}$ and replace it by another material of high quality adequately compacted in place.

\section{V.1 Foundation sited on a stiff to very stiff silt and clay deposit}

If this solution is retained (i.e. to place the foundations on the stiff to very stiff silt and clay deposit), the bearing capacity values grouped in Table 7 were suggested for the footing design. These values included a safety factor of 3 against any failure and limit the total settlement to $25 \mathrm{~mm}$ and the relative settlement to $20 \mathrm{~mm}$.

Table 7. A llo wable bearing capacity-stiff silt and clay deposit

\begin{tabular}{|c|c|c|c|}
\hline \multicolumn{4}{|c|}{ Allowable bearing capacity (kPa) } \\
\hline \multirow{2}{*}{$\begin{array}{l}\text { Transformer foundation } \\
\qquad(4.0 \times 8.0 \mathrm{~m})\end{array}$} & \multicolumn{3}{|c|}{\begin{tabular}{|c|}
$\begin{array}{c}\text { Isolated circular or rectangular foundation } \\
\text { (diameter or width, } \mathrm{m} \text { ) }\end{array}$ \\
\end{tabular}} \\
\hline & $<1.2$ & $1.2-1.8$ & $1.8-2.4$ \\
\hline 200 & 300 & 240 & 180 \\
\hline
\end{tabular}

\section{V.2 Excavation and replacement of liquefiable sand}

In this case, the top layer of the ground composed mainly of liquefiable sand is completely excavated and replaced by granular soil which could have a spread particle size distribution. The excavation should be performed within the first 4.0 to $5.0 \mathrm{~m}$ until reaching the silt and clay horizon. It is necessary to provide an adequate system of pumping and drainage in order to maintain the level of water to a minimu $\mathrm{m}$ depth of $0.6 \mathrm{~m}$ below the base of the excavated area during the whole working period. The surface of the silt and clay layer will have to be as horizontal as possible, and a slope of $10 \%$ will be accepted as maximu m limit. The granular fill should be placed in layers of $300 \mathrm{~mm}$ thickness and compacted to at least $95 \%$ of the maximum dry density of the material measured in laboratory by means of the modified Proctor test (P.M.). The compacted fill should be extended under the foundation with a slope of $1.0 \mathrm{~V} ; 1.0 \mathrm{H}$ up to the base of the excavation. Worthwhile to note that, it is required to embed the foundations to a minimum depth of $1.8 \mathrm{~m}$ for assure a frost protection (Toronto area). If these conditions are respected, the bearing capacity values grouped in Table 8 could be used for footings' design. These values included a safety factor of 3 against any failure and limit the total settlement to $25 \mathrm{~mm}$ and the relative settlement to $20 \mathrm{~mm}$.

Table 8. A llo wable bearing capacity - Excavation and fill option

\begin{tabular}{|c|c|c|c|c|}
\hline \multicolumn{5}{|c|}{ Allowable bearing capacity (kPa) } \\
\hline \multirow{2}{*}{$\begin{array}{c}\text { Granular soil } \\
\text { specification * }\end{array}$} & $\begin{array}{c}\text { Transformer } \\
\text { foundation } \\
(\mathbf{4 . 0} \times \mathbf{8 . 0} \mathbf{~ m})\end{array}$ & $\begin{array}{c}\text { Isolated circular or rectangular foundation } \\
\text { (diameter or width, } \mathbf{m})\end{array}$ \\
\cline { 3 - 5 } & 200 & 300 & 240 & 180 \\
\hline$>35 \%$ of gravel & 200 & $\mathbf{1 . 2}-\mathbf{1 . 8}$ & $\mathbf{1 . 8}-\mathbf{2 . 4}$ \\
\hline $20-35 \%$ of gravel & 160 & 260 & 200 & 140 \\
\hline$<20 \%$ of gravel & 130 & 220 & 150 & 100 \\
\hline
\end{tabular}

\section{V.3 Ground improvement by stone columns}

Soil improvement measures can be considered to limit excessive settlement and reduce or eliminate the risk of liquefaction. The improvement processes available and which could potentially apply in the present case are many. However, due to the varied nature of soils encountered in place (sand, silt and clay), the ground improvement solutions retained are limited to jet grouting and vibro-replacement by stone columns.

The jet grouting process consists on the densification and reinforcement of the soil by injecting a very viscous grout or a special concrete at high pressure. This can be applied to any kind of soils and can reach a depth of about $50 \mathrm{~m}$. This method permits to reduce settlement to a large extend but the mitigation for the potential of soil liquefaction is less efficient that the stone column method. In the case of liquefaction of deposit B, a drag-down (negative skin friction) will be developed by the soil above the water table on the grouted columns due to the irregularities of their surfaces. 
The vibro-replacement by stone columns consists of substituting soil columns by densified granular materials. In contrast with the vibroflotation process, this method can be applied to any kind of soils, and can reach a depth typically of 30 $\mathrm{m}$. This method can permit a significant reduction on settlement when the area replacement ratio was near $25 \%$. The high permeability of the granular material of the columns permits the dissipation of the soil water pressure and reduces the potential of liquefaction of the soil. For the present investigation, in order to get a bearing capacity of about $150 \mathrm{kPa}$ (calculated by the model of Hughes and Withers [3] and using an angle of shearing resistance $\varphi=42^{\circ}$ ), it is recommended to proceed with stone columns of $40 \mathrm{~cm}$ diameter and spaced center to center by about $2.0 \mathrm{~m}$. Furthermore, the stone columns should have a minimum of $10.0 \mathrm{~m}$ length (i.e. embedded by $5.0 \mathrm{~m}$ in the silt-clay deposit) in order to dissipate efficiently the pore water pressure in this deposit (i.e. deposit C).

\section{V.4 Ground improvement by dynamic compaction}

This ground improvement technique can also be used as an alternative for stabilizing the site of the project. By considering the nature and grading of the brown sand layer, and the level of groundwater table, we could consider dynamic compaction technique, described herein, to eliminate or to reduce, to an acceptable extend, the liquefaction potential of this layer.

The liquefiable brown sand layer could be treated in place by dynamic compaction which improves its geotechnical properties. The method consists in ramming the ground surface by a series of impacts of strong magnitude or intensity generated by means of concrete or steel mass dropped in freefall [4].

In the case of dynamic compaction, it is recommend to measure the permeability of the soil before the compaction process using wells of observation, such as wells installed in boreholes BH-01-10, BH-02-10, BH-07-10, BH-09-10 and $\mathrm{BH}-14-10$. This action is needed in order to check that the ground can be effectively drained and that dynamic compaction will not generate excessive interstitial pore water pressure which would harm uniform densification of compacted layers. Worthwhile to note that, in this project, a deep compaction is not required. In any case, the depth of the soil to be treated is more or less 5.0 meters.

The bearing capacity should be evaluated in place before and after dynamic compaction to verify the efficiency of the treatment by means of dynamic penetration tests or any other in situ evaluation method of soil bearing capacity. It should be noted that it is necessary to guarantee a bearing capacity of $200 \mathrm{kPa}$ for the projected structures.
Moreover, it is necessary to guarantee total settlement less than $25 \mathrm{~mm}$ under working loads. Once the soil is densified and after confirmation of the requested soil bearing capacity by means of dynamic penetration test or any in situ method, the structures could be built on conventional footings sited directly on the improved soil.

By considering the vibrations caused by dynamic compaction, we recommend that, adjacent constructions, if any, are inspected before and after the beginning of work to monitor any cracks.

\section{V.5 Pile foundations}

The foundation of the new structure can be supported by driven piles embedded in the bed of stiff to very stiff silt and clay up to a sufficient depth in order to give the required bearing capacity.

Preliminary calculations of the bearing capacity of circular piles of different lengths and different diameters were performed and the results obtained are represented in Figure 5. Worthy to note that these values were obtained by considering the lateral resistance (positive skin friction) on the pile in the layer of liquefiable sand as being null. Moreover, an average estimated value of undrained shear strength of silt and clay, $C_{u}=120 \mathrm{kPa}$ was considered.

In this project, the piles should traverse the liquefiable layer (i.e. deposit B) and should be embedded in the deposit $\mathrm{C}$ by a minimum of 1.2 times le depth of the liquefiable deposit. In this case, the length of the piles should be around $12.0 \mathrm{~m}$ According to Figure 5 and for example, for a pile of a diameter $B=0.30 \mathrm{~m}$ and $12 \mathrm{~m}$ length, the allowable bearing capacity is approximately $200 \mathrm{kN}$. This value of bearing capacity should include the loads (dead and live) of the foundations, filling materials and the ground slab. Moreover, this value includes a safety factor of 3 against any.

However, the structural loads applied on the piles must be increased by the load induced by negative skin friction. Negative skin friction will induced by liquefaction of brown sand and will be caused by excessive settlement of soils situated above the water table. Preliminary calculations showed that the value of this friction is around 30 $\mathrm{KN}$ for a pile of $0.4 \mathrm{~m}$ in diameter. Nevertheless, this negative friction could be reduced to an acceptable level if the piles are encapsulated in smooth casing or covered by a layer of bitumen.

\section{CONCLUSION}

A geotechnical investigation was carried out at Chatham-Kent (Ontario) in order to build a new electrical station on a liquefiable site. Several treatment methods and foundation systems were proposed. It is believed that the more suitable solutions for the present project are either excavating 
and replacing the liquefiable soil (section 5.2) or adopting a system of deep foundations (section 5.5).

However, if both methods are confronted with some financial constraints, we suggest to maintain pile foundations for the line entrance and transformer pads, and to adopt ground improvement techniques (stone columns or dynamic compaction) for the remaining parts.

\section{REFERENCES}

[1]. Engineer Manuals (1994), Design of Sheet Pile Walls, EM 1110-2-2504, U.S. Army Corps Engineers, Washington, DC 203141000 .

[2]. Prakash, S. (1981). Future Problems of Geotechnical Earthquake Engineering, International Convention of American Society of Civil Engineers, New York, Preprint no. 81-87, pp. 1-12

[3]. Hughes, J.M.O. and Withers, N.J. (1974). Reinforcing of Soft Cohesive Soils with Stone Columns, Ground Engineering, Vol. 7, No. 3, pp 42-49.

[4]. Canadian Foundation Engineering Manual (2006), Fourth Edition, published by the 